Titus Maccius Plautus: Curculio, 24. ledna 2018, kino Scala, Brno. Překlad: Daniela Urbanová, Eliška Poláčková, Radek Černoch, Tomáš Weissar; režie: Tomáš Weissar, Kateřina Hvižd'ová; dramaturgie: Eliška Poláčková; hudba: Miloš Štědroň.

\title{
Lubor Kysučan
}

Ve středu 24. ledna 2018 bylo brněnské univerzitní kino Scala svědkem nejen pro klasické filology historické události - české premiéry dosud nepřeložené komedie Tita Maccia Plauta Darmojed (Curculio). Do posledního místa zaplněné kino a zasloužený potlesk a uznání publika vydaly jasné svědectví o tom, že i antická, téměř třiadvacet století stará komedie může promlouvat i k dnešnímu divákovi - a to nejen tomu, který se orientuje $\mathrm{v}$ antické kultuře a reáliích.

Úspěch inscenace je dán nejen kvalitou textu klasika antické komedie, ale primárně i profesionálním a mezioborovým přístupem a trpělivou spoluprací smíšeného týmu studentů, doktorandů a pedagogů z Ústavu klasických studií FF MU, Katedry divadelních studií FF MU i Právnické fakulty MU. Práce na inscenaci probíhala s podporou projektu Fondu rozvoje Masarykovy univerzity MUNI/FR/1394/2016 Řimská komedie: inscenačni workshop. Příprava inscenace byla výsledkem víceleté práce, jejíž první fází byl vlastní překlad Plautova textu, vytvářený v překladatelském semináři doc. PhDr. Daniely Urbanové, Ph.D., hlavní iniciátorky celého projektu. Výsledky této práce autorka představila 22. zář́ 2017 s pozitivními ohlasy ve svém referátu na konferenci Hortus Graeco-Latinus Cassoviensis II. Záměrem překladatelské práce bylo vytvořit čtivý a živý překlad, který osloví současného diváka a současně zachová obsahová i estetická specifika Plautovy hry, která jsou vázána na dobovou kulturu. V případě Plautova textu se tak překladatelé museli vyrovnat nejen s odlišným jazykově-literárním, ale i historickým kontextem, což je vzhledem k množství jazykových hříček založených na dvojsmyslech i košatému situačnímu humoru vázanému na dobové reálie vskutku ne- lehký úkol. Překladatelé se s ním ovšem vyrovnali nanejvýš důvtipně a podařilo se jim vytvořit věrný a současně živý český překlad a úspěšně se vyrovnat s dnes již jen obtížně srozumitelnými pasážemi včetně dvojsmyslných narážek i odkazů na dobové právní reálie a substituovat je adekvátními a plně pochopitelnými českými analogiemi. Tyto analogie představují mnohdy humorné aktualizace, které vtipně, nikoliv nepřirozeně anachronicky odkazují k dnešní době. Jejich projevem jsou i vtipně inovovaná jména hlavních hrdinů (bankéř Hypotékus, kuplír Pornotékus, mladík Romantikus, voják Poclusemclus). Ostatně s podobnou metodou přistupovali $\mathrm{k}$ antice ve svých školských hrách adaptujících klasickou tematiku už Jan Amos Komenský i jeho pokračovatelé z řad profesorů jezuitských a piaristických gymnázií. Lze říci, že právě tato transformace antického humoru zachovávající jeho charakter a styl a současně prostřednictvím nikoliv násilných aktualizací jej zprostředkující modernímu divákovi byla tím nejobtížnějším úkolem jak překladatelů, tak inscenátorů hry, úkolem, který se mimořádně podařil na úrovni, kdy se publikum výborně bavilo jako při inscenaci jakékoliv moderní komedie. Velmi důvtipným řešením bylo vytvoření nové postavy Referencie Podčarové - personifikované poznámky pod čarou vysvětlující publiku potřebný kontext. Stejně úspěšnou jako překlad byla i vlastní inscenace. Rovněž její přípravě byl věnován samostatný kurs, v němž se studenti mohli seznámit se všemi úskalími antické dramatiky i jejích moderních aktualizací.

Přičteme-li k tomu stejně profesionální výpravu, hudbu renomovaného skladatele a muzikologa Miloše Štědroně a originální herecké 
výkony, z nichž nejeden výrazně přesáhl úroveň studentského ochotnického divadla, výsledkem je živé představení, které má potenciál oslovit daleko širší publikum než poměrně úzkou obec klasických filologů. Dokladem úspěchu jsou ohlasy ve dvou celostátních médiích (reportáže v České televizi a rozhovor v Českém rozhlasu se spoluautorkou přkladu teatroložkou Dr. Eliškou Poláčkovou). Závěrem lze konstatovat, že se jedná o mimořádný tvůrčí počin, spojující v sobě odborné i umělecké kvality, který na jedné straně představuje profesionální interpretaci antického díla a současně na straně druhé jeho neméně profesionální aktualizaci pro širší moderní publikum. Je potěšující, že se recenzovaná inscenace - za podpory uděleného divadelního grantu DILIA 2018 - dočkala dalších úspěšných repríz v Brně a v Ostravě a další jsou ve výhledu (Mikulov, LŠKS Kuks). Navíc tak autoři inscenace navázali na starou tradici, mající své kořeny již v pozdní renesanci, kdy studenti městských škol, řádových gymnázií a univerzit ve spolupráci se svými profesory inscenovali antické hry, které přispívaly nejen ke kulturnímu povznesení publika a jeho vzdělání o vlastních antických kořenech naší kultury, ale i k stmelení univerzitní komunity. Plně obsazené univerzitní kino je dokladem toho, že i po této stránce tento výjimečný kulturní počin splnil svůj účel.

doc.PhDr. Lubor Kysučan, Ph.D. / lubor.kysucan@osu.cz

Department of Latin Language and Culture

University of Ostrava, Faculty of Arts

Reální 5, 70103 Ostrava, Czech Republic 